\title{
Market risk in demutualised self-listed stock exchanges: An international analysis of selected time-varying betas
}

\author{
ANDREW WORTHINGTON ${ }^{\mathrm{a}, *} \&$ HELEN HIGGS ${ }^{\mathrm{b}}$ \\ ${ }^{a}$ School of Accounting and Finance, University of Wollongong, Wollongong NSW 2522, Australia \\ ${ }^{\mathrm{b}}$ School of Economics and Finance, Queensland University of Technology, Brisbane QLD 4001, Australia
}

\begin{abstract}
This paper examines market risk in four demutualised and self-listed stock exchanges: the Australian Stock Exchange, the Deutsche Börse, the London Stock Exchange and the Singapore Stock Exchange. Daily company and MSCI index returns provide the respective asset and market portfolio data. A bivariate MA-GARCH model is used to estimate time-varying betas for each exchange from listing until 7 June 2005. While the results indicate significant beta volatility, unit root tests show the betas to be mean-reverting. These findings are used to suggest that despite concerns that demutualised and self-listed exchanges entail new market risks that merit regulatory intervention, the betas of the exchange companies have not changed significantly since listing. However, market risk does vary considerable across the exchanges, with mean time-varying betas of 0.56 for the Deutsche Börse, 0.66 for the London Stock Exchange, 0.78 for the Singapore Stock Exchange, and 0.95 for the Australian Stock Exchange.
\end{abstract}

JEL classification: C32, C51, G18

Keywords: Time-varying betas; moving average; bivariate GARCH; demutualization and self-listing, exchanges

\section{Introduction}

The ownership and governance structures of securities exchanges around the world have changed dramatically in the last decade or so. Starting with the Stockholm Stock Exchange in 1993, the Helsinki Stock Exchange in 1995 and the Copenhagen Stock Exchange in 1996, the major theme has been the abandonment of the traditional mutual structure, where the exchange is owned by trade-executing brokers, in favour of a corporate form of ownership, where stock in the exchange may be owned by non-broker third-parties [see Appendix 1 for the breakdown of global exchanges by legal status]. At the same time, these structural changes have opened up opportunities for the merger of exchanges and related settlement systems, and the formation of joint ventures and alliances with other exchanges and settlement systems, both nationally and internationally. And concomitantly, the changes in ownership and governance have raised regulatory issues relating to the ability of a for-profit,

\footnotetext{
* Corresponding author: School of Accounting and Finance, University of Wollongong, Wollongong NSW 2522 , Australia. Tel.+61 (0)2 4272 3616; Fax.+61 (0)2 4272 4297; Email. andreww@uow.edu.au
} 
often monopolistic, exchange to properly exercise its responsibilities regarding trading, settlement and the surveillance of market behaviour including, in an increasing number of instances, its own.

It is the latter, whether self-regulation is inconsistent with demutualization (read for-profit) and (often, though not always) self-listing (read non-intermediary owners), that has most dominated discussion of these global changes in ownership and governance. Certainly, it has been high on the agenda for securities regulators. Consider the Australian Stock Exchange. While its demutualization and subsequent self-listing was not associated with a complete rewrite of market provisions, the amended legislation did include: (i) provisions that no person (or group of associated persons) should own more than five (now fifteen) percent of its share capital, (ii) a fuller articulation of the obligations of exchanges, especially for market monitoring and supervision, (iii) requirements for reports detailing compliance with supervisory obligations and powers to enforce compliance, and (iv) other powers directed to the Australian Securities and Investment Commission (ASIC) as listing authority and supervisor.

The exchange itself says as much: "As both a market operator and commercial entity, ASX works closely with oversight bodies to ensure the appropriate supervision of its own market and the management of any conflicts of interest that may arise with its for-profit activities. This successful balance underpins the integrity of the market" (ASX 2005). Similarly, in the Singapore Exchange the five business divisions are kept separate from the regulatory division. On top of this, two additional safeguards are in place. One is in the form of the Monetary Authority of Singapore, the exchange's regulator, which supervises the exchange's compliance with its listing rules. The other is in the form of a conflicts committee, set up to consider all possible conflicts of interest and to notify the regulator of all identified conflicts (SGX 2005).

In general, the balance of opinion of both regulators and exchanges worldwide is that exchange demutualization (whether not-for-profit or for-profit), with and without self-listing, is no less consistent with the development and enforcement of appropriate listing and disclosure standards, surveillance and discipline, financial and operational compliance, and fair and equitable treatment of customers, than mutualisation (Steil 2002). However, an additional concern that has received rather less attention is whether the act of demutualization and listing itself has facilitated risky business activities that may be of concern to regulators, which simply did not arise when the exchanges were mutual. 
For example, as early as 2001 the IOSCO Technical Committee expressed concern that “...the profit-seeking actions of a demutualised exchange may provide further encouragement to enter businesses other than those directly ancillary to its traditional trade execution functions" (IOSCO 2001: 14). This, it suggests, entails new financial risks for the exchange that may merit regulatory intervention, such as the imposition of "...firewalls to protect the resources necessary to run the exchange's core activities". From an Australian perspective, Segal (2001) likewise discusses how the self-listed Australian Stock Exchange's “...role as a market regulator and its role as a commercialised entity able to pursue business initiatives in many directions" opened up the scope for conflict early on, and the potential for new forms of risk through global links, including clearing and settlement arrangements.

Demutualization and self-listing patently appear to have played a major role in freeing-up the ability of exchanges to engage in many commercial activities - part of their stated purpose after all. For example, just a few months after demutualization the Australian Stock Exchange (2005) announced a merger proposal (unsuccessfully) with the Sydney Futures Exchange, within a year entered a strategic alliance with NASDAQ, formed a joint venture with Perpetual Trustees in 2000, created an operational trading link with both North America and Singapore in 2001, launched a futures market in 2002, and by 2003 had entered MOUs with the Philippines, Thailand, Singapore, Tokyo, Hong Kong, Shanghai and Shenzhen exchanges.

A similar pace of expansion in less-core non-domestic commercial activities, is found in many other demutualised exchanges [see Deutsche Börse (2005), London Stock Exchange (2005), Singapore Stock Exchange (2005)]. And yet other differences have arisen in business conduct. For instance, the World Federation of Exchanges 2003 Cost and Revenue Survey of fifty member exchanges concluded that demutualised exchanges generated about twice as much service income from (less-traditional) market data dissemination as did mutuals, and much less from (more-traditional) transaction fees. Likewise, while all demutualised and listed exchanges in this survey identified themselves as being for-profit, more than one-third of member exchanges and less than one-half of association exchanges did not identify profits as a business goal (WFE 2003).

Clearly, the financial risk of exchanges may have increased substantially relative to their (traditional) domestic market with the process of demutualization. This is especially likely to be the case for self-listed exchanges, where ownership is usually more dispersed (albeit with limitations on maximum holdings) than demutualised-only entities whose ownership is (sometimes) concentrated in the hands of prior mutual holders, domestic financial 
intermediaries, and even governments. Accordingly, this paper aims to ascertain the changes in risk in selected demutualised and self-listed stock exchanges and examine if this risk has increased substantially during the period since listing and the freeing-up of commercial behaviour. The measure of risk (beta) used is relative and domestic as this is thought likely to be of most relevance to national regulators. The paper itself is divided into four sections. Section explains the data used in the analysis and presents some brief descriptive statistics. Section 3 discusses the methodology employed. The results are dealt with in Section 4. The paper ends with some brief concluding remarks.

\section{Data and statistics}

Four self-listed stock exchanges are included in the analysis: the Australian Stock Exchange (ASX), Germany's Deutsche Börse Group AG (DEB), the London Stock Exchange plc (LSE) in the United Kingdom and the Singapore Exchange Limited (SGX). To start with, the Australian Stock Exchange was formed in 1987 through the amalgamation of six state-based exchanges. In October 1998 the exchange demutualised and became a self-listed company. The exchange's revenues (value in $\mathrm{A} \$ \mathrm{~m}$ and percentage of total in brackets) for the financial year ending 30 June 2005 comprised equities, trading, clearing and settlement $(\$ 118.4,42 \%)$, listings $(\$ 71.5,26 \%)$, derivatives $(\$ 44.0,16 \%)$, market data $(\$ 32.1,11 \%)$ and other sources (\$13.7, 5\%). The Deutsche Börse Group became a listed company in February 2001. Its main revenue segments ( $€ \mathrm{~m}$ and percentage of total in brackets) for the calendar year ending 31 December 2004 were the Xetra $^{\circledR}$ trading platform and the Frankfurt Stock Exchange (€216.3, 14.9\%), its Eurex derivatives subsidiary (€407.4, 28.1\%), fixed interest and equity banking, custody and settlement services subsidiary, Clearstream $(€ 578.3,39.9 \%)$, market data and analytics $(€ 121.7,8.4 \%)$ and information technology for service provision to international exchanges $(€ 125.4,8.7 \%)$.

The London Stock Exchange, one of the world's oldest exchanges, owes its present form to an amalgamation with eleven British and Irish regional exchanges in 1973. As part of the 1986 deregulation 'Big Bang' it became a private limited company, listing on its main market in July 2001. For the year ending 31 March 2005 the company’s revenues (£m and percentage of total in brackets) were derived from information services (£110.0, 42.0\%), broker services (£100.0, 38.0\%), issuer services (£35.0, 14.0\%), derivatives services (£7.0, 3.0\%) and other services (£8.0, 3.0\%). Lastly, the Singapore Exchange Limited was formed in 1999 through the merger of the Stock Exchange of Singapore and the Singapore International Monetary 
Exchange. In November 2003, it became the first exchange in the Asia-Pacific to be listed via public offer and private placement. The exchanges revenues for the year ending 30 June 2005 ( $\mathrm{S} \$ \mathrm{~m}$ and percentage of total in brackets) were sourced from securities (\$143.7, 52.3\%) including clearing fees, processing income and access fees, derivatives clearing $(\$ 49.6$, $18.1 \%$ ), and 'stables' (\$81.4, 29.6\%) - comprising account maintenance and corporate action fees, terminal and connection fees and price information fees, and the sale of software and computing services.

The raw data employed in the study are the daily prices of the four stock exchange companies and the daily market value-weighted equity indices for Australia (AUS), Germany (GER), the United Kingdom (UK) and Singapore (SNG). The company data is obtained from Bloomberg and the market indices from Morgan Stanley Capital International (MSCI). All prices are in US dollars. MSCI market indices are used (rather than, say, the Australian All Ordinaries, Germany's DAX, the United Kingdom's FTSE100 and Singapore's Straits Times) because of their consistency in depth, breadth and construction. The selection of domestic indices rather than a single international index is also preferred, following suggestions by McKenzie et al. (2000: 1) that: "the forecast error metrics suggest that the estimates of conditional risk relative to the domestic market index are preferred to estimates generated using the world market index, irrespective of the industry concerned. While not to suggest time-varying betas estimated relative to a domestic index are universally superior, these results suggest that they are preferable in certain circumstances". The series span dissimilar sampling periods given the varying self-listing dates. The end date for all series is 7 June 2005 with the ASX starting on 14 October 1998, DEB on 5 February 2001, LSE on 22 July 2001 and SGX on 22 November 2000. The sample periods represent the longest series of data possible.

\section{$<$ TABLE 1 HERE $>$}

Table 1 presents a summary of descriptive statistics of the daily returns for the four exchanges and the market portfolios. Samples means, medians, standard deviations, skewness and kurtosis, and the Jacque-Bera statistic and $p$-value are reported. The mean continuously compounded daily returns for the exchanges range from 0.0517 for SGX to 0.1086 for ASX, while the returns for the market portfolios range from -0.0142 for GER to 0.0422 for AUS. The standard deviations for the returns for the stock exchanges range from 1.7866 (DEB) to 1.9810 (LSE). On this basis, and of the four exchanges, ASX and DEB are the least volatile, while LSE and SGX are the most volatile. The standard deviations for the returns for the 
market portfolios range from 1.0799 (AUS) to 1.6768 (GER). Of the four market portfolios, AUS and UK are the least volatile, while GER and SNG are the most volatile. A visual perspective on the volatility of returns can be gained from the plots in Figure 1.

\section{$<$ FIGURE 1 HERE $>$}

The distributional properties of all eight series appear non-normal. Given that the sampling distribution of skewness is normal with mean 0 and standard deviation of $\sqrt{6 / T}$ where $\mathrm{T}$ is the sample size, all of the return series are significantly skewed. All of the returns of the exchanges are positively skewed, with the exception of DEB, indicating the greater likelihood of large increases in returns than falls, while the returns of the market portfolios are all negatively skewed, indicating the greater probability of large decreases in portfolio returns than rises. The kurtosis, or degree of excess, in the returns are also large, ranging from 5.6874 for DEB to 23.8819 for LSE with the exchanges and from 5.0489 for GER to 5.8241 for the UK with the market portfolios. All of the return series are leptokurtic or fat-tailed. Given the sampling distribution of kurtosis is normal with mean 0 and standard deviation of $\sqrt{24 / T}$ where $\mathrm{T}$ is the sample size, then all estimates are once again statistically significant at any conventional level. Finally, the calculated Jarque-Bera statistics and corresponding $p$-values in Table 1 are used to test the null hypotheses that the daily distribution of exchange and market portfolio returns is normally distributed. All $p$-values are smaller than the .01 level of significance suggesting the null hypothesis can be rejected. None of these returns are then well approximated by the normal distribution.

\section{Methodology}

The standard capital asset pricing model (CAPM) includes asset betas (market risk) that are constant. But starting with Fabozzi and Francis (1978) the suggestion is made that beta coefficients may move randomly through time rather than remain constant. Bos and Newbold (1984) argue such variation may be due, in part, to the influence of microeconomic factors, including operational changes in the case of company betas. A large number of studies have subsequently estimated time-varying betas in a variety of contexts with several different methods, including Bollerslev et al. (1988), Engle and Rodrigues (1989), Hall et al. (1989), Bodurtha and Mark (1991), Ng (1991), Lin et al. (1992), Faff et al. (1992), Koutmos et al. 
(1994) Wells, C. (1994) Giannopoulos, K. (1995), Episcipos (1996), Gonzalez-Rivera (1996) Brooks et al. (1998), Tai, C.S. (2000) and Choudhry (2002; 2005).

But before proceeding with the methodology used in this paper, a question arises as to what beta magnitudes may be reasonably expected for the four exchanges. To start with, in the absence of any information regarding the systematic risk of the firm, the best estimate of the equity beta of any stock is unity. However, this is an infinitely more reasonable assumption for the exchanges in question. This is because, for the most part, exchange operations are focused on areas that are likely to be highly related to overall market activity and performance. For example, the principal sources of revenue for most exchanges are listings, trading, clearing and settlement and the provision of market data. Of course, equity betas depend on both the operations of the company and its capital structure, and companies in the same industry with similar operations may have different equity betas if their capital structures differ. Accordingly, while it is not the objective of the current study, an asset beta for the exchanges could be obtained by unlevering the equity betas.

A bivariate GARCH (BEKK) model is developed to examine the joint processes relating the daily returns of the asset (the exchange) and the market portfolio. Bollerslev et al. (1988), Engle and Rodrigues (1989), Hall et al. (1989), Ng (1991), Koutmos et al. (1994), Giannopoulos $(1995)$ and Choudhry $(2002 ; 2005)$ apply some form of multivariate GARCH models to estimate time-varying betas and Bollerslev et al. (1992), Bera and Higgins (1993) and Engle and Kroner (1995) provide detailed analysis of these models more generally. The following conditional mean return equation accommodates the returns for the exchange $(i=1)$ and the market portfolio $(i=2)$ and follows a moving average (MA) process represented as:

$$
r_{i t}=\mu_{i}+\varepsilon_{i t}-\theta_{i} \varepsilon_{i t-1} \quad i=1,2
$$

where $r_{\mathrm{it}}=\left(r_{1 \mathrm{t}}, r_{2 \mathrm{t}}\right)^{\prime}$ is a $2 \times 1$ vector of returns from the exchange and the market portfolio; the $2 \times 1$ vector of random errors, $\varepsilon_{i t}$, is the innovation for each return at time $t$ with its corresponding $2 \times 2$ conditional variance-covariance matrix, $H_{t}$; the market information available at time $t-1$ is represented by the information set $I_{t-1}$ such that $\varepsilon_{t} \mid I_{t-1} \sim N\left(0, H_{t}\right)$; and the $2 \times 1$ vector, $\mu_{\mathrm{i}}$, represents the long-term drift coefficients for the returns of the exchange and the market portfolio. Susmel and Engle (1994) first suggest non-synchronous trading promotes negative serial correlation and the MA, term $\theta_{1} \varepsilon_{\mathrm{it}-1}$, is included in the conditional mean return equation to capture this effect of non-synchronous trading. 
Engle and Kroner (1995) present various multivariate GARCH models with variations to the conditional variance-covariance matrix of equations. For the purposes of this analysis, the BEKK (Baba, Engle, Kraft and Kroner) model is employed, whereby the variance-covariance matrix of equations depends on the squares and cross products of innovation $\varepsilon_{t}$ and volatility $H_{t}$ for each market lagged one period. One important feature of this specification is that it builds in sufficient generality, allowing the conditional variances and covariances to influence each other, and, at the same time, does not require the estimation of a large number of parameters (Karolyi 1995). The model also ensures the condition of a positive semi-definite conditional variance-covariance matrix in the optimisation process, and is a necessary condition for the estimated variances to be zero or positive. The BEKK parameterisation for the bivariate $\operatorname{GARCH}(1,1)$ model is written as:

$$
\begin{aligned}
& H_{t}=C^{\prime} C+A^{\prime} \varepsilon_{t} \varepsilon_{t-1} A+B^{\prime} H_{t-1} B
\end{aligned}
$$

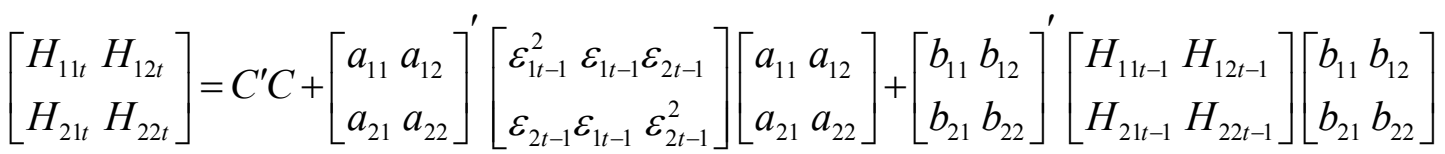

or equation (3) can be simply denoted by:

$$
\begin{aligned}
& \hat{H}_{11 t}=c_{11}+a_{11} \varepsilon_{1 t-1}^{2}+b_{11} \hat{H}_{11 t-1} \\
& \hat{H}_{12 t}=c_{12}+a_{12} \varepsilon_{1 t-1} \varepsilon_{2 t-1}+b_{12} \hat{H}_{12 t-1} \\
& \hat{H}_{22 t}=c_{22}+a_{22} \varepsilon_{2 t-1}^{2}+b_{22} \hat{H}_{22 t-1}
\end{aligned}
$$

where $\mathrm{A}$ is a $2 \times 2$ symmetric matrix of constants and A and $\mathrm{B}$ are $2 \times 2$ symmetric matrices of parameters. The elements $a_{11}$ and $a_{22}$ represent the ARCH process or degree of innovation in the returns of the asset and returns of the market portfolio. The $a_{12}$ element represents the degree of innovation of the returns of the asset and the returns of the market portfolio on the conditional variance. The elements $b_{11}$ and $b_{22}$ represent the GARCH process or degree of persistence in the returns of the asset and returns of the market portfolio. The $b_{12}$ element represents the degree of persistence of the returns of the asset and the returns of the market portfolio on the conditional variance. Significance of the covariance parameters implies strong interaction between the asset and market portfolio returns. With the assumption that the random errors are normally distributed, the log-likelihood function for the model is:

$$
L(\theta)=-\frac{T n}{2} \ln (2 \pi)-\frac{1}{2} \sum_{t=1}^{T}\left(\ln \left|H_{t}\right|+\varepsilon_{t}^{\prime}\left|H_{t}^{-1}\right| \varepsilon_{t}\right)
$$


where $T$ is the number of observations, $n$ is the number of markets, $\theta$ is the vector of parameters to be estimated, and all other variables are as previously defined. The BHHH (Berndt, Hall, Hall and Hausman) algorithm is used to produce the maximum likelihood parameter estimates and their corresponding asymptotic standard errors.

The time varying beta $(\beta)$ for asset $(1)$ is denoted as:

$$
\beta_{1, t}=\hat{H}_{12, t} / \hat{H}_{22, t}
$$

where $\hat{H}_{12, t}$ is the estimated conditional covariance between the exchange and the market portfolio returns and $\hat{H}_{22, t}$ is the estimated conditional variance of the market portfolio from the bivariate GARCH model. As the conditional variance and conditional covariance are time dependent, then the stock exchange beta will also be time dependent.

Lastly, the Ljung-Box $Q$ statistic is used to test for independence of higher relationships as manifested in volatility clustering by the GARCH model (Huang and Yang 2000: 329). This statistic is given by:

$$
Q=T(T+2) \sum_{j=1}^{p}(T-j)^{-1} r^{2}(j)
$$

where $r(j)$ is the sample autocorrelation at $\operatorname{lag} j$ calculated from the noise terms and $T$ is the number of observations. $Q$ is asymptotically distributed as $\chi^{2}$ with $(p-k)$ degrees of freedom and $k$ is the number of explanatory variables. This test statistic is used to test the null hypothesis that the model is free of serial correlation and independent of higher order ARCH processes.

\section{Empirical results}

The estimated coefficients and standard errors for the conditional mean return equations are presented in Table 2. All estimations are made using the S-PLUS ${ }^{\circledR}$ statistical software with the GARCH add-on module. Four separate equations are specified, one for each exchange and market combination. The long-term drift $\left(\mu_{1}\right)$ coefficients in all four exchanges are positive and significant. These long-term drift components represent the daily non-stochastic trend and on this basis, the ASX (0.1149) has the largest daily trend, followed by LSE (0.1029), DEB (0.1027) and SGX (0.0681). The daily non-stochastic trend in the market portfolios is also highest in Australia, then the United Kingdom, Singapore and Germany: AUS (0.0728), followed by UK (0.0584), SNG (0.0455) and GER (0.0402). Of the MA $\left(\theta_{1}\right)$ coefficients in 
the exchanges, ASX (0.0322) is positive and significant, while SGX (-0.0744) is negative and significant. In the market portfolios $\left(\theta_{2}\right)$ the MA is positive and significant for AUS (0.0471), and negative and significant for the UK (-0.0957). Significance in these MA terms is often argued to be the result of different news being observed by different investors, the same news being interpreted differently by investors or the same news being interpreted by investors in the same way, but at different times. The process of information passing backwards and forwards between different investors at different times then generates the pattern of negative and positive serial correlation.

\section{$<$ TABLE 2 HERE $>$}

The conditional variance covariance equations incorporated in the paper's bivariate MAGARCH methodology effectively captures the volatility and cross-volatility spillovers among and between the exchange and the market portfolio. Table 3 presents the estimated coefficients for the conditional variance covariance equations. These quantify the effects of the lagged own and cross innovations and lagged own and cross volatility persistence on the own and cross volatility of the stock exchange and portfolio markets. To start with, the owninnovation or $\mathrm{ARCH}$ spillovers $\left(a_{11}\right)$ for the exchanges in all equations are significant indicating the presence of significant ARCH effects, while the lagged volatility or GARCH spillovers $\left(b_{11}\right)$ are also significant and larger in magnitude. The respective innovation and volatility spillovers are 0.0474 and 0.9414 in ASX, 0.1008 and 0.7802 in DEB, 0.2320 and 0.5747 in LSE and 0.0692 and 0.8363 in SGX. The sum of the ARCH and GARCH effects is less than one in all exchanges, implying a mean-reverting conditional volatility process. That is, the shocks are transitory in nature.

\section{$<$ TABLE 3 HERE $>$}

The own-innovation spillovers in all market portfolios $\left(a_{22}\right)$ are also significant, and as with the exchanges, smaller in magnitude than the lagged volatility spillovers $\left(b_{22}\right)$. AUS has the largest lagged volatility spillover effect of 0.9231 while UK has the smallest lagged volatility spillover effects of 0.8891 . Combined with exchange estimates, this means that past volatility shocks in both the ASX and AUS markets have a greater effect on future ASX and AUS volatility over time than the past volatility shocks in the other exchanges and markets examined. Once again, the $\mathrm{ARCH}$ and $\mathrm{GARCH}$ effects sum to less than one in all four markets, indicating a mean-reverting volatility process. In terms of cross-volatility for the $\mathrm{ARCH}\left(a_{12}\right)$ and GARCH $\left(b_{12}\right)$ parameters, all estimated coefficients are again significant 
with the cross-innovation GARCH effects larger than the cross-innovation ARCH effects in all equations. The sum of these coefficients measures the cross-volatility persistence spillover effects, and these indicate that cross-volatility persistence ranges from 0.8920 in LSE/UK and 0.9700 in ASX/AUS.

\section{$<$ TABLE 4 HERE $>$}

Finally, the Ljung-Box (LB) $Q$-statistics for the standardized residuals and the squared standardized residuals in Table 4, reveals that these are insignificant in all of the estimated equations (all have $p$-values greater than 0.05). The insignificance of the Ljung-Box (LB) $Q$ statistics for all equations indicates the absence of serial correlation while the insignificance of the squared standardized residuals means it is unnecessary to include a higher-order ARCH process in the bivariate GARCH model.

\section{$<$ TABLE 5 HERE $>$}

Figure 1 plots each exchange's time-varying beta using the estimated conditional covariance between the exchange and the market portfolio and the estimated conditional variance of the market portfolio from the bivariate GARCH model. All the betas are clustered below unity implying the exchange are less risky than their respective market portfolios. A linear trend line is also included in each graph, with a small downward trend for the ASX betas, and small upward trends for the DEB, LSE and SGX betas. Table 5 includes the mean and variance of these exchange beta estimates. As shown, the ASX has the highest beta (0.9527), followed by the SGX (0.7802), then the LSE (0.6589) and finally the DEB (0.5692). Remembering the MSCI are equity indices, the range of betas is not difficult to account for. For instance, the business operations of the ASX are still aligned with the domestic equity market in much the same manner as its mutualised form. DEB, however, has much more diversified operations: "[The] Deutsche Börse has a broader basis than all its competitors: its products and services portfolio covers the entire process chain: from securities and derivatives trading through the settlement of transactions and provision of market information right up to the development and operation of electronic trading systems" (DEB 2005). There is also clearly much variation in these time-varying betas, with the ASX being the most variable, then LSE, DEB and SGX. 
Table 5 also includes the results of unit root tests comprising the ADF and PP $t$-statistics and $p$-values and the KPSS LM-statistic and asymptotic significance. In the case of the former the null hypothesis of a unit root is tested against the alternative of no unit root (stationary). For the latter, the null hypothesis of no unit root is tested against the alternative of a unit root (nonstationary). The unit root tests in Table 5 are supportive of the hypothesis that the time varying betas for all four exchanges are stationary. The ADF and PP t-statistics reject the null hypothesis of a unit root at the .01 level or lower, thereby indicating that the time-varying betas for all four exchanges are stationary. For the KPSS tests of the null hypothesis of no unit root, the LM-statistics do not exceed the asymptotic critical value at the 0.10 level for AUS (0.0484) and LON (0.0508), at the 0.05 level for GER (0.1252) and at the 0.01 level for SNG (0.1632). The KPSS unit root tests fail to reject the required null, thus implying there is insufficient evidence to support the view that the time-varying betas are nonstationary.

The Breusch-Pagan test (not shown) is used to detect the presence of heteroskedasticity or non-homogeneity of variances in the regression disturbances of the time-varying betas. The Breusch-Pagan test assumes in the null hypothesis there are no heteroskedastistic patterns in the variances of the disturbances. The test statistic is the product of the number of observation and the unadjusted $\mathrm{R}^{2}$, where the unadjusted $\mathrm{R}^{2}$ is obtained from the regression of the squared residuals against the explanatory variables. The test statistic is distributed as a Chi-Squared distribution with the number of explanatory variables as the degrees of freedom. The calculated Breusch-Pagan test statistics and $p$-values are 40.9137 (0.0000) for AUS, 19.9203 (0.0000) for GER, $6.1003(0.0135)$ for $\mathrm{LON}$ and $102.1354(0.0000)$ for SNG. The test statistics reject the null at the 0.05 level of significance, implying evidence of heteroskedasticity in all four time-varying beta series.

\section{Conclusions and policy implications}

This paper uses a bivariate MA-GARCH to estimate the time-varying betas for four demutualised and self-listed stock exchanges: the Australian Stock Exchange, the Deutsche Börse, the London Stock Exchange and the Singapore Stock Exchange. Unit roots tests show that despite significant variability in each exchange's beta over time, they are covariance stationary and mean reverting. This has obvious and well-known for implications the capital asset pricing model, efficient markets hypothesis, event studies, and more importantly, the forecasting of exchange returns. 
However, the primary focus of this analysis is instead on whether significant changes in market risk have arisen in securities exchanges through the process of demutualization and self-listing. While none of the exchanges has been listed for more than seven years, there is still ample evidence that the betas for these exchanges are stationary and have neither trended up nor down since listing. This suggests that despite ample evidence of operational and financial change since demutualization, and concerns that risky business decisions could impact upon the ability of exchanges to perform their traditional monitoring and supervisory role, there has been no significant change in financial risk.

Clearly, there is still much unknown concerning demutualised and self-listed securities exchanges and their impacts. Empirical research, for example, could follow the theoretical models of Hart and Moore (1996) and Pirrong (2000) and attempt to account for the ongoing demutualization movement. While the former has been criticised for over-emphasising the role of member heterogeneity and the apparent trade-off between exchange costs and profits, as against the role of internationalisation and corporatisation of membership and market competition, and the latter because he fails to take account of the choice of demutualised exchanges to take an additional step of widening their ownership by self-listing (Steil 1996; 2002), they provide a convenient starting point. Another line of work could examine the relative performance (as variously defined) of demutualised exchanges, in reference to both their own mutual form and current mutuals. The same work could examine differences, if any, between the roughly equal number of demutualised but not listed exchanges and listed exchanges. Finally, there is scope for work to merely assay the current situation regarding ownership and governance structures in securities exchanges.

\section{References}

Australian Stock Exchange $(2005)<$ http://www.asx.com/> accessed 5 August.

Bera, A.K., Higgins, M.L. (1993) ARCH models: Properties, estimation and testing, Journal of Economic Surveys 7, 305-366.

Bodurtha, J., Mark, N. (1991) Testing the CAPM with time-varying risk and returns, Journal of Finance 46, 1485-1505.

Bollerslev, T., Chou, R.Y., Kroner, K.F. (1992) ARCH modelling in finance: A review of the theory and empirical evidence, Journal of Econometrics 52, 5-59.

Bollerslev, T., Engle, R., Wooldrige, J. (1988) A capital asset pricing model with time-varying covariances. Journal of Political Economy 96, 116- 131.

Bos, T., Newbold, P. (1984) An empirical investigation of the possibility of stochastic systematic risk in the market model, Journal of Business 57, 35-41.

Brooks, R.D., Faff, R.W., McKenzie, M.D. (1998) Time varying beta risk of Australian industry portfolios: A comparison of modelling techniques, Australian Journal of Management 23, 1-22.

Choudhry, T. (2002) The stochastic structure of time varying beta: Evidence from UK companies, Manchester School, 70(6), 768-791. 
Choudhry, T. (2005) Time-varying beta and the Asian financial crisis: Evidence from Malaysian and Taiwanese firms, Pacific Basin Finance Journal, 13, 93-118.

Deutsche Börse Group (2005) < http://www.deutsche-boerse.com/> accessed 5 August.

Di Noia, C. (2001) Customer-Controlled Firms: the Case of Financial Exchanges, in Capital Markets in the Age of the Euro, edited by G. Ferrarini, K. Hopt, and E. Wymeersch. London: Kluwer.

Engle, C., Rodrigues, A. (1989) Tests of international CAPM with time-varying covariances. Journal of Applied Econometrics 4, 119- 138.

Engle, R.F., Kroner, K.F. (1995) Multivariate simultaneous generalized ARCH, Econometric Theory 11, 122150.

Episcopos, A. (1996) Stock return volatility and time varying betas in the Toronto stock exchange, Journal of Business Economics 35, 28-38.

Fabozzi, F., Francis, J. (1978) Beta as a random coefficient. Journal of Financial and Quantitative Analysis 13, 101-116.

Faff, R.W., Lee, J.H.H., Fry, T.R.L. (1992) Time stationarity of systematic risk: Some Australian evidence, Journal of Business Finance and Accounting 19, 253-270.

Giannopoulos, K. (1995) Estimating the time-varying components of international stock markets risk, European Journal of Finance 1, 129- 164.

Gonzalez-Rivera, G. (1996) Time varying risk: The case of the American computer industry, Journal of Empirical Finance 2, 333-342.

Hall, S., Miles, D., Taylor, M. (1989) Modelling asset prices with time-varying betas, Manchester School 57, 340-356.

Hart, O. and Moore, J. (1996) The governance of exchanges: Members' cooperatives versus outside ownership, Oxford Review of Economic Policy 12(4), 53-69.

Huang, B.N., Yang, C.W. (2000) The impact of financial liberalization on stock price volatility in emerging markets. Journal of Computational Economics 28, 321-339.

International Organisation of Securities Commissions (2001) Issues Paper on Exchange Demutualization, June.

Karolyi, G.A. (1995) A multivariate GARCH model of international transmissions of stock returns and volatility: The case of the United States and Canada. Journal of Business and Economic Statistics, 13, 11-25.

Koutmos, G., Lee, U., Theodossiou, P. (1994) Time-varying betas and volatility persistence in international stock markets. Journal of Economics and Business 46, 101- 112.

Lin, W., Chen, Y., Boot, J.C. (1992) The dynamic and stochastic instability of betas: Implications for forecasting stock returns, Journal of Forecasting 11, 517- 541.

London Stock Exchange (2005) <http://www.londonstockexchange.com/> accessed 5 August.

McKenzie, M.D. Brooks, R.D and Faff, R.W. (2000) The use of domestic and world market indexes in the estimation of time-varying betas, Journal of Multinational Financial Management 10, 91-106.

$\mathrm{Ng}$, L. (1991) Tests of the CAPM with time-varying covariances: A multivariate GARCH approach. Journal of Finance 46, 1507-1521.

Pirrong, C. (2000) A theory of financial exchange organization, Journal of Law and Economics 43, 437-71.

Segal, J. (2001) Market demutualization and privatisation: The Australian experience, in Public Documents of the XXVI ${ }^{\text {th }}$ Annual Conference of the International Organisation of Securities Commissions, 23-29 June, Stockholm, Sweden.

Segal, J. (2002) Market demutualization and cross-border alliances: The Australian experience, paper presented at the Fourth Roundtable on Capital Market Reform in Asia, Tokyo, Japan.

Singapore Stock Exchange (2005) <http://info.sgx/com/> accessed 5 August.

Steil, B. (2002) Changes in the Ownership and Governance of Securities Exchanges: Causes and Consequences, Brookings-Wharton Papers on Financial Services.

Steil, Benn. (1996) "The ISD and the Regulation of European Market Structure." In The European Equity Markets: The State of the Union and an Agenda for the Millennium, edited by Benn Steil. London: European Capital Markets Institute and the Royal Institute of International Affairs.

Susmel, R. and Engle, R. (1994) Hourly volatility spillovers between international equity markets, Journal of International Money and Finance, 13, 3-25.

Tai, C.S. (2000) Time-varying market, interest rate and exchange rate risk premia in the US commercial bank stock returns. Journal of Multinational Financial Management, 10, 397-420. 
Wells, C. (1994) Variable betas on the Stockholm exchange 1971-1989, Applied Economics 4, 75-92.

World Federation of Exchanges (2003) Cost and Revenue Survey 2003, available at http://www.worldexchanges.com. 
TABLE 1. Summary statistics of daily returns for self-listed stock exchange companies and national market portfolios

\begin{tabular}{|c|c|c|c|c|c|c|c|c|}
\hline \multirow{2}{*}{$\begin{array}{l}\text { Markets } \\
\text { Exchange/market portfolio }\end{array}$} & \multicolumn{2}{|c|}{ Australia } & \multicolumn{2}{|c|}{ Germany } & \multicolumn{2}{|c|}{ United Kingdom } & \multicolumn{2}{|c|}{ Singapore } \\
\hline & ASX & AUS & DEB & GER & LSE & UK & SGX & SNG \\
\hline Number of observations & 1734 & 1734 & 1131 & 1131 & 1012 & 1012 & 1184 & 1184 \\
\hline Start date & $14 / 10 / 1998$ & $14 / 10 / 1998$ & $5 / 02 / 2001$ & $5 / 02 / 2001$ & $22 / 07 / 2001$ & $22 / 07 / 2001$ & $22 / 11 / 2000$ & $22 / 11 / 2000$ \\
\hline End date & $7 / 06 / 2005$ & $7 / 06 / 2005$ & $7 / 06 / 2005$ & $7 / 06 / 2005$ & $7 / 06 / 2005$ & $7 / 06 / 2005$ & $7 / 06 / 2005$ & $7 / 06 / 2005$ \\
\hline Mean & 0.1086 & 0.0422 & 0.0680 & -0.0142 & 0.0540 & 0.0183 & 0.0517 & 0.0093 \\
\hline Median & 0.1053 & 0.0517 & 0.0187 & 0.0378 & 0.0000 & 0.0158 & 0.0000 & 0.0323 \\
\hline Standard deviation & 1.8883 & 1.0799 & 1.7866 & 1.6768 & 1.9810 & 1.1903 & 1.8926 & 1.1951 \\
\hline Skewness & 0.4133 & -0.4012 & -0.1285 & -0.1528 & 1.6062 & -0.2139 & 0.2777 & -0.1293 \\
\hline Kurtosis & 14.7054 & 5.4295 & 5.6874 & 5.0489 & 23.8819 & 5.8241 & 19.2067 & 5.7279 \\
\hline Jarque-Bera statistic & 9949 & 473 & 343 & 202 & 18822 & 344 & 12973 & 370 \\
\hline Jarque-Bera $p$-value & 0.0000 & 0.0000 & 0.0000 & 0.0000 & 0.0000 & 0.0000 & 0.0000 & 0.0000 \\
\hline
\end{tabular}

Notes: MSCI - Morgan-Stanley Capital International, ASX - Australian Stock Exchange Limited, AUS - MSCI Australia, DEB - Deutsche Börse Group, GER - MSCI Germany, LSE - London Stock Exchange plc, UK - MSCI United Kingdom, SGX - Singapore Stock Exchange Limited, SNG - MSCI Singapore. 
FIGURE 1. Daily returns for self-listed stock exchange companies and market portfolios
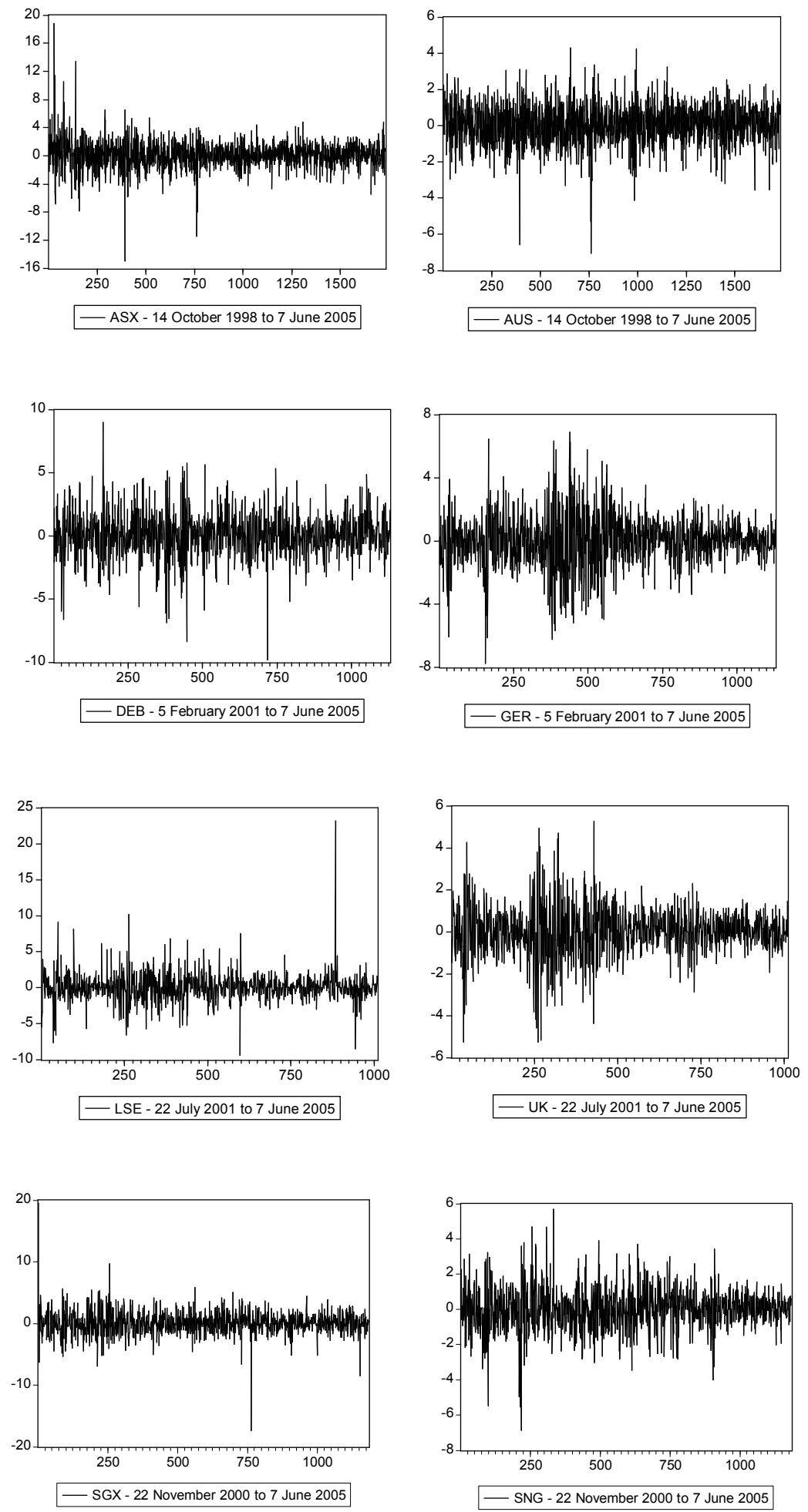

Notes: MSCI - Morgan-Stanley Capital International, ASX - Australian Stock Exchange Limited, AUS - MSCI Australia, DEB - Deutsche Börse Group, GER - MSCI Germany, LSE - London Stock Exchange plc, LSE MSCI United Kingdom, SGX - Singapore Stock Exchange Limited, SNG MSCI Singapore. 
TABLE 2. Estimated coefficients for conditional mean return equations

\begin{tabular}{|c|c|c|c|c|c|c|c|c|c|c|c|c|}
\hline & \multicolumn{3}{|c|}{ ASX } & \multicolumn{3}{|c|}{ DEB } & \multicolumn{3}{|c|}{ LSE } & \multicolumn{3}{|c|}{ SGX } \\
\hline & $\begin{array}{l}\text { Estimated } \\
\text { coefficient }\end{array}$ & $\begin{array}{l}\text { Standard } \\
\text { error }\end{array}$ & $p$-value & $\begin{array}{l}\text { Estimated } \\
\text { coefficient }\end{array}$ & $\begin{array}{c}\text { Standard } \\
\text { error }\end{array}$ & $p$-value & $\begin{array}{l}\text { Estimated } \\
\text { coefficient }\end{array}$ & $\begin{array}{l}\text { Standard } \\
\text { error }\end{array}$ & $p$-value & $\begin{array}{l}\text { Estimated } \\
\text { coefficient }\end{array}$ & $\begin{array}{c}\text { Standard } \\
\text { error }\end{array}$ & $p$-value \\
\hline$\mu_{1}$ & 0.1149 & 0.0379 & 0.0012 & 0.1027 & 0.0496 & 0.0192 & 0.1029 & 0.0510 & 0.0219 & 0.0681 & 0.0464 & 0.0715 \\
\hline$\theta_{1}$ & 0.0332 & 0.0200 & 0.0482 & -0.0193 & 0.0299 & 0.2590 & -0.0468 & 0.0369 & 0.1026 & -0.0744 & 0.0296 & 0.0061 \\
\hline$\mu_{2}$ & 0.0728 & 0.0264 & 0.0029 & 0.0402 & 0.0347 & 0.1231 & 0.0584 & 0.0257 & 0.0115 & 0.0455 & 0.0314 & 0.0739 \\
\hline$\theta_{2}$ & 0.0471 & 0.0210 & 0.0123 & -0.0223 & 0.0323 & 0.2451 & -0.0957 & 0.0322 & 0.0015 & 0.0162 & 0.0294 & 0.2908 \\
\hline
\end{tabular}

Notes: ASX - Australian Stock Exchange Limited, DEB - Deutsche Börse Group, LSE - London Stock Exchange plc, SGX - Singapore Stock Exchange Limited.

TABLE 3. Estimated coefficients for conditional variance covariance equations

\begin{tabular}{ccccccccccccccc}
\hline & \multicolumn{3}{c}{ ASX } & \multicolumn{4}{c}{ DEB } & \multicolumn{3}{c}{ LSE } & \multicolumn{3}{c}{ SGX } \\
Estimated \\
coefficient & $\begin{array}{c}\text { Standard } \\
\text { error }\end{array}$ & $p$-value & $\begin{array}{c}\text { Estimated } \\
\text { coefficient }\end{array}$ & $\begin{array}{c}\text { Standard } \\
\text { error }\end{array}$ & $p$-value & $\begin{array}{c}\text { Estimated } \\
\text { coefficient }\end{array}$ & $\begin{array}{c}\text { Standard } \\
\text { error }\end{array}$ & $p$-value & $\begin{array}{c}\text { Estimated } \\
\text { coefficient }\end{array}$ & $\begin{array}{c}\text { Standard } \\
\text { error }\end{array}$ & $p$-value \\
\hline$c_{11}$ & 0.0404 & 0.0063 & 0.0000 & 0.3811 & 0.0769 & 0.0000 & 0.8090 & 0.0939 & 0.0000 & 0.3006 & 0.0879 & 0.0003 \\
$a_{11}$ & 0.0474 & 0.0041 & 0.0000 & 0.1008 & 0.0196 & 0.0000 & 0.2320 & 0.0140 & 0.0000 & 0.0692 & 0.0168 & 0.0000 \\
$b_{11}$ & 0.9414 & 0.0045 & 0.0000 & 0.7802 & 0.0340 & 0.0000 & 0.5747 & 0.0320 & 0.0000 & 0.8363 & 0.0407 & 0.0000 \\
$c_{12}$ & 0.0328 & 0.0083 & 0.0000 & 0.0301 & 0.0130 & 0.0102 & 0.0655 & 0.0198 & 0.0005 & 0.0406 & 0.0124 & 0.0005 \\
$a_{12}$ & 0.0424 & 0.0052 & 0.0000 & 0.0435 & 0.0119 & 0.0001 & 0.0702 & 0.0186 & 0.0001 & 0.0361 & 0.0088 & 0.0000 \\
$b_{12}$ & 0.9276 & 0.0112 & 0.0000 & 0.9171 & 0.0239 & 0.0000 & 0.8218 & 0.0423 & 0.0000 & 0.9156 & 0.0183 & 0.0000 \\
$c_{22}$ & 0.0434 & 0.0146 & 0.0015 & 0.0214 & 0.0087 & 0.0069 & 0.0225 & 0.0080 & 0.0026 & 0.0278 & 0.0085 & 0.0005 \\
$a_{22}$ & 0.0405 & 0.0077 & 0.0000 & 0.0793 & 0.0114 & 0.0000 & 0.0905 & 0.0158 & 0.0000 & 0.0770 & 0.0100 & 0.0000 \\
$b_{22}$ & 0.9231 & 0.0182 & 0.0000 & 0.9121 & 0.0130 & 0.0000 & 0.8891 & 0.0197 & 0.0000 & 0.9039 & 0.0119 & 0.0000 \\
\hline
\end{tabular}

Notes: ASX - Australian Stock Exchange Limited, DEB - Deutsche Börse Group, LSE - London Stock Exchange plc, SGX - Singapore Stock Exchange Limited. 
TABLE 4. Ljung-Box test statistics

\begin{tabular}{lrrrrrrrr}
\hline & \multicolumn{2}{c}{ ASX } & \multicolumn{2}{c}{ DEB } & \multicolumn{2}{c}{ LSE } & \multicolumn{2}{c}{ SGX } \\
& Statistic & p-value & Statistic & \multicolumn{1}{c}{ p-value } & \multicolumn{1}{c}{ Statistic } & p-value & Statistic & p-value \\
\hline \multirow{2}{*}{ Standardized residuals } & 20.1000 & 0.0653 & 10.72 & 0.5533 & 6.4970 & 0.8890 & 15.9200 & 0.1948 \\
Squared standardized & 19.2700 & 0.0821 & 13.34 & 0.3445 & 11.2680 & 0.5061 & 10.1600 & 0.6021 \\
residuals & 4.0370 & 0.9828 & 3.445 & 0.9915 & 1.8450 & 0.9996 & 1.5050 & 0.9999 \\
& 8.6160 & 0.7353 & 12.032 & 0.4431 & 12.5400 & 0.4033 & 8.6370 & 0.7335 \\
\hline
\end{tabular}

TABLE 5. Time-varying beta mean, variance and unit root tests

\begin{tabular}{lrrrr}
\hline Statistic & \multicolumn{1}{c}{ ASX } & \multicolumn{1}{c}{ DEB } & \multicolumn{1}{c}{ LSE } & \multicolumn{1}{c}{ SGX } \\
\hline Mean & 0.9527 & 0.5692 & 0.6589 & 0.7802 \\
Variance & 0.1067 & 0.0440 & 0.0893 & 0.0311 \\
ADF $t$-statistic & -5.9127 & -6.3448 & -8.6195 & -6.4240 \\
ADF $p$-value & 0.0000 & 0.0000 & 0.0000 & 0.0000 \\
PP $t$-statistic & -6.0778 & -6.3866 & -8.5212 & -6.4998 \\
PP $p$-value & 0.0000 & 0.0000 & 0.0000 & 0.0000 \\
KPSS $t$-statistic & 0.0484 & 0.1254 & 0.0508 & 0.1632 \\
KPSS $p$-value & 0.1000 & 0.0500 & 0.1000 & 0.0100 \\
\hline
\end{tabular}

Notes: For Augmented Dickey-Fuller (ADF) tests hypotheses are $\mathrm{H}_{0}$ : unit root, $\mathrm{H}_{1}$ : no unit root (stationary). The lag orders in the $\mathrm{ADF}$ equations are determined by the significance of the coefficient for the lagged terms. The Phillips-Peron (PP) unit root test hypotheses are $\mathrm{H}_{0}$ : unit root, $\mathrm{H}_{1}$ : no unit root (stationary). Intercepts and trends are included in the series. The Kwiatkowski, Phillips, Schmidt and Shin (KPSS) unit root test hypotheses are $\mathrm{H}_{0}$ : no unit root (stationary), $\mathrm{H}_{1}$ : unit root. The asymptotic critical values for the KPSS LM test statistic at the $.10, .05$ and .01 levels are $0.119,0.146$ and 0.216 respectively.

FIGURE 2. Time-varying betas for self-listed stock exchange companies
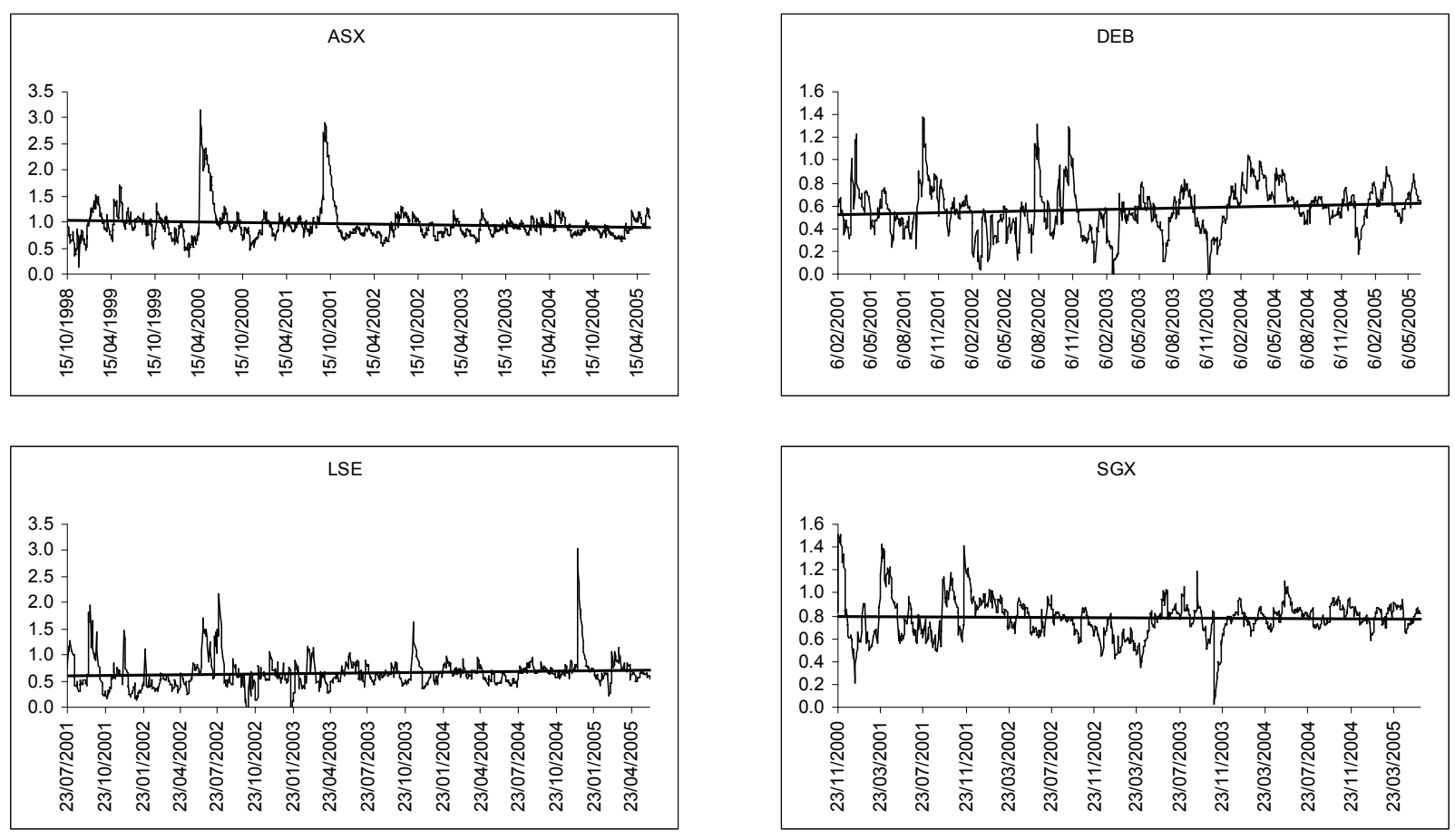
APPENDIX 1. Ownership and governance status of members of the World Federation of Exchanges (2003)

$\begin{array}{ll}\text { Structure } & \text { Description } \\ \text { Member- } & \begin{array}{l}\text { Private companies, often } \\ \text { owned, }\end{array} \\ \text { with paid-up share capital. } \\ \text { companies } & \begin{array}{l}\text { Almost always sole owners } \\ \text { of exchange with strong link } \\ \text { between ownership and } \\ \text { intermediation rights }\end{array}\end{array}$

Demutualised, Registered as private limited but not listed companies, but not as listed exchanges companies.

Listed Publicly listed, freely-traded exchanges shares on exchange they operate.

$\begin{array}{ll}\begin{array}{l}\text { Associations, } \\ \text { mutuals }\end{array} & \begin{array}{l}\text { No share capital with } \\ \text { restricted access to } \\ \text { membership }\end{array} \\ \text { Other } & \begin{array}{l}\text { Includes, but is not limited } \\ \text { to, state-owned exchanges } \\ \text { and government agencies }\end{array}\end{array}$

\section{$\underline{\text { Number }} \underline{\text { Members }}$}

11 Bursa Malaysia, Luxembourg Stock Exchange, Chicago Board Options Exchange, New York Stock Exchange, Colombo Stock Exchange, Shenzhen Stock Exchange, Irish Stock Exchange, Tel Aviv Stock Exchange, Jakarta Stock Exchange, Wiener Börse AG, Ljubljana Stock Exchange

14 American Stock Exchange, Mexico Stock Exchange, BME Spanish Exchanges, NASDAQ, Borsa Italiana SpA, National Stock Exchange of India Ltd., Bourse de Montréal, Osaka Securities Exchange, Budapest Stock Exchange Ltd., Oslo Børs, Copenhagen Stock Exchange, Taiwan Stock Exchange Corp., HEX Integrated Markets Ltd., Tokyo Stock Exchange

13 Athens Exchange, London Stock Exchange, Australian Stock Exchange, New Zealand Exchange, Bolsa de Valores de Lima, Philippine Stock Exchange, Bolsa de Comercio de Santiago, Singapore Exchange, Deutsche Börse AG, Stockholmsbörsen, Euronext, TSX Group, Hong Kong Exchanges \& Clearing

6 JSE Securities Exchange South Africa, Bolsa de Valores do São Paulo, Korea Stock Exchange, Shanghai Stock Exchange, BSE The Stock Exchange Mumbai, SWX Swiss Exchange

6 Bolsa de Comercio de Buenos Aires, Stock Exchange of Tehran, Istanbul Stock Exchange, Stock Exchange of Thailand, Malta Stock Exchange, Warsaw Stock Exchange 